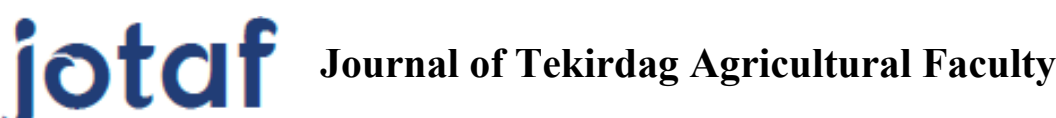

\section{Tüketicilerin Süt ve Süt Ürünleri Tercihlerinin Analizi}

Analysis of Preferences for Milk and Milk Products of Consumers

\author{
Sait ENGINDENiZ ${ }^{*}$, Turğay TAŞKIN ${ }^{2}$, Awo Abdoulaye GBADAMONSI ${ }^{3}$, \\ Aysar Shihab AHMED ${ }^{4}$ Alpha SALOUM CISSE ${ }^{5}$, Ahmed Fathy SEIOUDY ${ }^{6}$, Çağrı \\ KANDEMİR $^{7}$, Nedim KOŞUM ${ }^{8}$
}

\section{$\ddot{O} \mathbf{z}$}

Türkiye'nin insan beslenmesinde önemli bir yer tutan süt tüketiminin gelişmiş ülkeler düzeyine ulaşabilmesi için, tüketicilerin süt tüketim tercihlerini belirlemeye yönelik araştırmaların yapılması, gerek tüketici, gerekse üretici firmalar açısından önemlidir. Bu bağlamda anılan çalışmaların il bazında ele alınarak değerlendirilmesi daha bilinçli tüketicilerin oluşmasında yardımcı olacaktır. Bu tür çalışmalar gelecek kuşakların sağlıklı olmasına da katkıda bulunacaktır. Bu araştırmada; İzmir' in Bornova ilçesinde süt ve süt ürünlerinin tüketim yapısı analiz edilmiş ve etkili olan sosyo-ekonomik faktörler incelenmiştir. Bir başka deyişle bu bir durum tespitine yönelik çalışma olmuştur. Bu araştırmanın amacı, İzmir'in Bornova ilçesinin kentsel kesiminde yaşayan hane halklarının süt ve süt ürünleri tüketim yapısı ile tercihlerini analiz etmektir. Araştırmada oransal örnek hacmi formülünden yararlanarak Bornova ilçe merkezinde yaşayan 271 hane halkı üyesinden anket yöntemiyle veriler elde edilmiş ve derlenmiştir. Toplanan verilerin analizinde, öncelikle hane halklarının demografik ve sosyo-ekonomik özellikleri ortaya konulmuş, daha sonra süt ve süt ürünleri satın alma ve tüketim davranışları analiz edilmiştir. Bu aşamada basit aritmetik ortalama ve yüzde hesaplamalarından yararlanılmıştır. Süt ve süt ürünlerine ilişkin görüş ve tutumların değerlendirilmesinde beşli likert ölçeği kullanılmışır. Hane halkı üyelerinin; \%66.42'si kadındır, \%47.97'si lise mezunudur, \%70.85'i evlidir, \%57.20'si ise halen bir işte çalışmaktadır. Görüşülen hane halkı üyelerinin \%93.36's1 süt, \%93.36's1 yoğurt, \%95.21'i de peynir tükettiğini belirtmiştir. Kişi başına yıllık süt tüketimi 37.43 lt, kişi başına yıllık yoğurt tüketimi $32.84 \mathrm{~kg}$, kişi başına yıllık peynir tüketimi ise $18.48 \mathrm{~kg}$ olarak saptanmıştır. Hayvansal protein tüketimini özendirmek, hijyenik koşullarda üretilmiş süt ve ürünlerinin tüketime sunulmasını sağlamak amacıyla toplumun bilgilendirilme ve bilinçlendirilmesine yönelik çalışmalar (afiş, broşür, belgesel ve spot filmler vb.) yapılmalıdır.

Anahtar Kelimeler: Süt, Süt ürünleri, Tüketim analizi, Tüketici tercihleri, Tüketici tutumları

\footnotetext{
1*Sorumlu Yazar/Corresponding Author: Sait ENGINDENiZ, Prof. Dr. Ege Üniversitesi, Ziraat Fakültesi, Tarım Ekonomisi Bölümü, İzmir E-mail: sait.engindeniz@ege.edu.tr (iD) OrcID: 0000-0002-7371-3330

${ }^{2}$ Turğay TAŞKIN, Prof. Dr. Ege Üniversitesi, Ziraat Fakültesi, Zootekni Bölümü, İzmir. E-mail: turgay.taskin@ege.edu.tr (iD) OrcID: 0000-0001-8528-9760.

${ }^{3}$ Awo Abdoulaye GBADAMONSI, Yük. Lis. Öğr. Ege Üniv, Ziraat Fak, Zootekni Bölümü, İzmir. E-mail: awoalamou@gmail.com (D) OrcID: 0000-0002-86114273.

${ }^{4}$ Aysar Shihab AHMED, Dok. Öğr. Ege Üniv., Ziraat Fak, Zootekni Bölümü, İzmir. E-mail: aysarshihab87@gmail.com (iD OrcID: 0000-0003-2990-6570

${ }_{5}^{5}$ Alpha SALOUM CISSE, Dok. Öğr. Ege Üniv., Ziraat Fakültesi, Zootekni Bölümü, İzmir. E-mail: alsacialsaci@gmail.com OrcID: 0000-0002-2944-9560

${ }^{6}$ Ahmed Fathy SEIOUDY, Dok. Öğr. Ege Üniv., Ziraat Fak., Zootekni Bölümü, İzmir. E-mail: ahmedseioudy@gmail.com OrcID: 0000-0001-6627-0781

${ }^{7}$ Çağrı KANDEMIR, Dr. Ege Üniversitesi, Ziraat Fakültesi, Zootekni Bölümü, İzmir. E-mail: cagri.kandemir@ege.edu.tr (D) OrcID: 0000-0001-7378-6962

${ }^{8}$ Nedim KOŞUM, Prof. Dr. Ege Üniversitesi, Ziraat Fakültesi, Zootekni Bölümü, İzmir. E-mail: nedim.kosum@ege.edu.tr (iD OrcID: 0000-0002-8253-5337

Atıf/Citation: Engindeniz S, Taşkın T, Gbadamonsı A. A., Ahmed A.S., Saloum Cısse A., Seıoudy A. F., Kandemir C.,Koşum N. . Tüketicilerin Süt ve Süt Ürünleri Tercihlerinin Analizi. Tekirdă̆ Ziraat Fakültesi Dergisi, 18 (3), 470-481.

CBu çalışma Tekirdağ Namık Kemal Üniversitesi tarafından Creative Commons Lisansı (https://creativecommons.org/licenses/by-nc/4.0/) kapsamında yayınlanmıştır. Tekirdağ 2021
} 


\begin{abstract}
Turkey's consumers to reach the level of developed countries consumption of milk holds an important place in human nutrition milk consumption is conducting research to determine their preferences, consumers need is an important content of both producers. In this context, evaluating the aforementioned studies on the basis of provinces will provide more conscious consumers. Thus, it will contribute to the health of future generations. In this study; The consumption structure of milk and dairy products in İzmir's Bornova district was analyzed and the influential socio-economic factors were examined. In other words, this is a case study. Bir başka deyişle bu bir durum tespitine yönelik çalışmadır. This study aims to analyze milk and milk products consumption patterns and preferences of households living in the urban part of Bornova district of Izmir. In the study, data was collected by survey method from 271 household members living in Bornova district center using the proportional sample size formula. In the analysis of the collected data, firstly, demographic and socio-economic characteristics of the households were revealed, and then the buying and consumption behaviors of milk and milk products were analyzed. At this stage, simple arithmetic means and percentage calculations were used. A five-point Likert scale was used to evaluate opinions and attitudes regarding milk and milk products. According to the results of this study, $66.42 \%$ of household members are women, $47.97 \%$ of them are high school graduates, $70.85 \%$ of they are married, and $57.20 \%$ of them are still working in a job. $93.36 \%, 93.36 \%$ and $95.21 \%$ of the household members interviewed stated that they consumed milk, yogurt and cheese, respectively. Annual milk consumption per capita was $37.43 \mathrm{lt}$, annual yogurt consumption per capita was $32.84 \mathrm{~kg}$, and annual cheese consumption per capita was $18.48 \mathrm{~kg}$. In order to encourage animal protein consumption and to ensure that milk and milk products produced under hygienic conditions are presented for consumption, activities for informing and raising awareness of the society (posters, brochures, documentaries and spot films etc.) should be prepared.
\end{abstract}

Keywords: Milk, Milk products, Consumption analysis, Consumer preferences, Consumer attitudes 


\section{Giriş}

Toplumlarda dengeli ve doğru beslenme, insanların gerek sağlıklarının korunması ve gerekse yaşamın devamlılığı için önemli bir rol oynamaktadır (MacDonald ve ark., 2011; Kayışçığlu ve İçöz, 2012; Örmeci Kart ve Demircan, 2014). Bu da ancak vücudun günlük ihtiyacı olan besin maddelerinin uygun miktarlarda alınmasıyla olasıdır. Anılan günlük besin maddeleri içinde önemli bir yeri olan süt ve süt ürünleri protein, kalsiyum, fosfor, B2 vitamini ve B12 vitamini olmak üzere birçok besin maddesi açısından bir gıda kaynağıdır (Ünal ve Besler, 2008). Hayvansal protein kaynaklarından biri olan süt ve süt ürünlerinde tüketim bakımında birçok ülke arasında farklılıklar söz konusudur (USK, 2019). Örneğin Avustralya, Norveç, İsveç, Fransa, Almanya gibi ülkelerde kişi başı yıllık süt tüketimi 300 kg, ABD'de ise 200 kg'ın üzerindedir. Bu değer Türkiye' de $41.5 \mathrm{~kg} / \mathrm{y} 1 \mathrm{lolmakla} \mathrm{birlikte,}$ bunun daha fazla olduğu tahmin edilmektedir (Demir ve ark., 2018; ZMO, 2019).

Önemli bir besin kaynağı olan süt, makro ve mikro birçok besin maddesini içerdiği için tüketiminin teşvik edilmesi sağlık uzmanları tarafından da önerilmektedir (Christopher ve Nordin 1997; TBSA, 2010; Meneses ve ark., 2012; Wetman, 2017). Süt proteinlerinin büyüme ve gelişmedeki önemi, kalsiyum emilimi ve bağışıklık üzerine olumlu etkilerinin olduğu, kanser riski ve kan basıncını azalttığı, vücut ağırlığını koruma yönünde etkili olduğu ve diş çürüklerine karşı koruyucu etkisi olduğu bilinmektedir (Black ve ark., 2002; Pereira ve ark., 2018). Süt ve süt ürünleri tüketimi, kalsiyumdan zengin olmaları nedeniyle, özellikle çocuk ve ergenlik döneminde olan çocuklarda kemik ve dişlerinin sağlıklı gelişmesi (Hasipek ve Kaleli, 2002; Mazıcıoğlu ve Öztürk, 2003; Karagözlü ve ark., 2005), yetişkinlerde ise kalp-damar hastalıkları, inme, yüksek tansiyon, Tip II diyabet, osteoporoz, kolon kanserinden korunmasının yanı sıra vücut gelişiminde de önemli bir rol oynamaktadır (TÜBER, 2015).

Türkiye'de farklı illerdeki tüketicilerin süt ve süt ürünleri tüketimleri ile ilgili birçok çalışma yapılmış ve bu çalışmalarda bireylerin süt ve süt ürünlerine yönelik tercihleri ve tüketim miktarları konusunda bazı bulgular elde edilmiştir (Demirci ve ark., 1998; Andiç ve ark., 2002; Selçuk ve ark., 2003; Şimşek ve ark., 2005; Çelik ve ark., 2005; Malatacık, 2006; Akbay ve Tiryaki, 2007; Cevger ve ark., 2008; Özel, 2008; Demircan ve ark., 2011; Erdal ve Tokgöz, 2011; Yayar, 2012; Şeker ve ark., 2012; Gözener ve Sayılı, 2013; Gündüz ve ark., 2013; Karakaya ve Akbay, 2014; Terin, 2014; Terin ve ark., 2015; Onurlubaş ve Çakırlar, 2016; Yazıcı, 2016; Niyaz ve İnan, 2016; Karakaya ve Kızıloğlu, 2018; Çebi ve ark., 2018; Dal ve ark., 2018; Para ve ark., 2018; Özyürek ve ark., 2019; Özbey, 2019).

Türkiye'nin insan beslenmesinde önemli bir yer tutan süt tüketiminin gelişmiş ülkeler düzeyine ulaşabilmesi için, tüketicilerin süt tüketim tercihlerini belirlemeye yönelik araştırmaların yapılması, gerek tüketici, gerekse üretici firmalar açısından önemlidir. Bu bağlamda, anılan çalışmaların il bazında ele alınarak yapılması ve çalışma sonuçlarının karar alıcılar tarafından değerlendirilmesiyle, politika ve stratejiler oluşturulabileceği ve daha bilinçli tüketicilerin oluşması sağlanacağı gibi, gelecek kuşakların sağlıklı olmasına da katkıda bulunulacaktır. Bu araştırmada; İzmir'in Bornova ilçesinde süt ve süt ürünlerinin tüketim yapısı analiz edilmiş ve etkili olan sosyoekonomik faktörler incelenmiştir. Bir başka deyişle bu bir durum tespitine yönelik çalışmadır. Araştırmada, küçük bir saha çalışması olması nedeniyle tüketicilerin süt ve süt ürünleri konusundaki tercihleri ortaya konmaya çalışılmıştır. Son olarak da konuyla ilgili bazı teknik ve ekonomik öneriler verilmiştir.

\section{Materyal ve Metot}

\subsection{Materyal}

$\mathrm{Bu}$ araştırmanın ana materyalini, İzmir'in Bornova ilçesinde hane halklarıyla yüz yüze yapılan anket çalışmalarından elde edilen veriler oluşturmaktadır. Ayrıca konuyla ilgili olarak daha önce yapılan araştırmaların sonuçlarından da yararlanılmıştır.

\subsection{Yöntem}

TÜİK, 2018 yılı Adrese Dayalı Nüfus Kayıt Sistemi sonuçlarına göre İzmir'in Bornova ilçesinde toplam nüfus 445.232 kişi, toplam hane sayısı ise 134.404 olarak bildirilmektedir (TÜİK, 2019). Bu araştırmanın ana kitlesini ilçedeki toplam hane sayısı oluşturmakta ve örnekleme yöntemiyle bir kısmı ile görüşülmesinin uygun olacağına karar verilmiştir. Bu amaçla aşağıdaki oransal örnek hacmi eşitlik (1) den yararlanılmıştır (Newbold, 1995). 


$$
n=\frac{N p(1-p)}{(N-1) \sigma^{2} p x+p(1-p)}
$$

Formülde;

$\mathrm{n}=$ Örnek hacmi

$\mathrm{N}=$ Toplam hane sayıs

$\mathrm{p}=$ Süt ve ürünleri tüketen hanelerin oranı (Maksimum örnek hacmi için 0.5 alınmıştır)

$\sigma^{2} \mathrm{px}=$ Varyansıdır.

Araştırmada \% 90 güven aralığı le \% 5 hata payı esas alınarak hesaplama yapılııs ve kapsama alınacak hane halkı sayısı 271 olarak saptanmıştır. Görüşülecek hane halklarının belirlenmesinde öncelikle mahalle ve sokak sayıları dikkate alınmıştır (Arslan ve ark., 2016; Özçıngırak ve Engindeniz, 2019). Bornova'da 44 mahalle bulunmaktadır. Araştırmada, her mahallenin üç sokağında beşer anket yapılması planlanmıştır. Bu yaklaşımla 18 mahalle rassal olarak belirlenmiştir. Araştırma anketleri, 2020 yılının Ocak-Şubat aylarında yapılmıştır.

Derlenen verilerin analizinde, öncelikle hane halklarının demografik ve sosyo-ekonomik özellikleri ortaya konulmuş, daha sonra süt ve ürünleri tüketim ve satın alma davranışları analiz edilmiştir. Araştırmada basit aritmetik ortalama ve yüzde hesaplamalarından yararlanılmıştır. Süt ve süt ürünlerine ilişkin görüş ve tutumların değerlendirilmesinde beşli likert ölçeği kullanılmıştır (Bilgin, 1995). Elde edilen sonuçlar çizelgeler halinde düzenlenerek yorumlanmıştır.

\section{Araştırma Sonuçları ve Tartışma}

Hane halklarının demografik ve sosyo-ekonomik özelliklerine yönelik bilgiler Tablo l'de verilmiştir. Görüşülen hane halkı üyelerinin \%66.42'si kadın, \%33.58'i ise erkektir. Yaşları ise 17-69 arasında değişmektedir. \%29.52'si 17-36, \%46.13'ü ise 37-56 yaşları arasındadır.

Hane halk1 üyelerinin \%47.97'si lise mezunu, \%27.31'i ise üniversite mezunu durumdadır. Hane halk1 üyelerinin $\% 70.85$ 'i evli, $\% 29.15$ 'i ise bekardır. Hane halkı üyelerinin $\% 57.20$ 'si halen bir işte çalışmaktadır. Çalışan hane halkı üyelerinin \%45.02'si özel sektörde, \%40.59'u ise kamu sektöründedir. \%14.39'unun ise kendine ait bir işyeri vardır. Hane halklarındaki birey sayısı 1-8 kişi arasında değişirken, \%64.21'i kendisine ait bir konutta ikamet etmektedir. Ortalama aylık gelir 1700-15000 TL arasında değişmekle birlikte hane halklarının \%47.23'ünün 4001-6000 TL arasında bir aylı gelire sahip olduğu saptanmıştır. Hanelerin \%59.41'inde gıda harcamaları içinde süt ve süt ürünleri harcamasının payı \%20'nin altındadır. Hanelerin ancak \%25.09’unda kronik bir rahatsızlı̆ıı olan birey bulunmaktadır.

Araştırma sonuçlarına göre, görüşülen hane halkı üyelerinin \%93.36'sı süt, \%93.36's1 yoğurt, \%95.21'i de peynir tükettiğini belirtmiştir. Kişi başına yıllık süt tüketimi 37.43 lt, yoğurt tüketimi $32.84 \mathrm{~kg}$, peynir tüketimi ise $18.48 \mathrm{~kg}$ olarak hesaplanmıştır. Bu veriler Ulusal Süt Konseyi verilerine de yakındır. Ulusal Süt Konseyinin (USK) 2018 yılı verilerine göre, Türkiye'de kişi başına yıllık ortalama süt tüketim miktarı 41.5 lt, kişi başına yılllk ortalama yoğurt tüketim miktarı $30.6 \mathrm{~kg}$, kişi başına yıllık ortalama peynir tüketim miktarı ise $18.4 \mathrm{~kg}$ olarak bildirilmektedir (USK, 2019). Yine İzmir'de yapılan bir araştırmada, hane halklarının yıllık kişi başı çiğ süt tüketimi 40.74 lt, yıllık kişi başı ambalajlı süt tüketimi ise 32.62 lt olarak saptanmıştır (Arslan ve ark., 2020).

Çalışmada, süt tüketim özelliklerine ait bilgiler Tablo 2'de verilmiştir. Süt tüketim sıklığının önemli bir kısmını haftada bir kaç gün (\%40.59) ve her gün (\%25.09) oranı oluşturmaktadır. Bu iki seçeneğin toplam oranı \%65 den fazla iken hiç süt tüketmeyenlerin oranı ise \%6.64 tür. Süt tüketimini sevmeyenlerin oranı $\% 4.43 \mathrm{iken}$, toplam sevenlerin oranı (çok ve az severim) $\% 75^{\prime}$ dir. Çalışmada, süt içme alışkanlığının önemli bir kısmı 10 yıl ve üstündedir (\%67.90). Gün içinde süt içme zamanı çoğunlukla sabah (\%43.48) olarak belirlenmiştir. Süt içmemenin en önemli nedenleri arasında sırasıyla; alerjik rahatsızlı (\% 33.33), tat (\% 27.77) ve kokusu (\%22.22) gelmiştir. Ankete katılan hane halkı üyeleri, sütü daha çok tam yağlı (\%44.27) tükettiklerini, tüketim sıcaklığını \%33.60 ile 1lık tercih ettiklerini ve daha çok sade (\%32.02) tükettiklerini belirtmişlerdir. Süt tüketiminde tür olarak daha çok inek sütünü (\%81.18) tercih ettikleri saptanmıştır. Pastörize süt tüketenlerinin oranı da \%62.45 ile en yüksek değere sahiptir. Süt tüketim miktarı hane başına aylık 10.45 lt, kişi başına yıllık 37.43 lt olarak hesaplanmıştır. 
Tablo 1. Hane halklarının demografik ve sosyo-ekonomik özellikleri

Table 1. Demographic and socio-economic characteristics of households

\begin{tabular}{|c|c|c|c|}
\hline Özellikler & & Sayı & $\%$ \\
\hline & Erkek & 180 & 66.42 \\
\hline \multirow[t]{2}{*}{ Cinsiyet } & Kadın & 91 & 33.58 \\
\hline & $17-36$ & 80 & 29.52 \\
\hline \multirow{2}{*}{ Yaş } & $37-56$ & 125 & 46.13 \\
\hline & $>57$ & 66 & 24.35 \\
\hline \multirow[t]{3}{*}{ Ĕ̆itim düzeyi } & İlköğretim & 67 & 24.72 \\
\hline & Lise & 130 & 47.97 \\
\hline & Yükseköğrenim & 74 & 27.31 \\
\hline \multirow[t]{2}{*}{ Medeni durumu } & Evli & 192 & 70.85 \\
\hline & Bekar & 79 & 29.15 \\
\hline \multirow[t]{2}{*}{ Çalışma durumu } & Çalışıyor & 155 & 57.20 \\
\hline & Çalışmıyor & 116 & 42.80 \\
\hline \multirow[t]{3}{*}{ Çalışma alanı } & Kamu & 110 & 40.59 \\
\hline & Özel & 122 & 45.02 \\
\hline & Kendi işi & 39 & 14.39 \\
\hline \multirow[t]{3}{*}{ Konut özellikleri } & Kendisine ait & 174 & 64.21 \\
\hline & Kirac1 & 88 & 32.47 \\
\hline & Diğer & 9 & 3.32 \\
\hline \multirow[t]{2}{*}{ Hanedeki birey sayıst } & $1-4$ & 189 & 69.74 \\
\hline & $>4$ & 82 & 30.26 \\
\hline \multirow[t]{3}{*}{ Hane aylık geliri (TL) } & $\leq 4000$ & 102 & 37.64 \\
\hline & $4001-6000$ & 128 & 47.23 \\
\hline & $>6001$ & 41 & 15.13 \\
\hline Hanede aylık süt ve süt ürünleri & $\leq 10$ & 48 & 17.71 \\
\hline harcamasınin gıda harcamaları & $11-20$ & 113 & 41.70 \\
\hline \multirow[t]{2}{*}{ içindeki oranı (\%) } & $21-30$ & 94 & 34.69 \\
\hline & $>31$ & 16 & 5.90 \\
\hline \multirow[t]{2}{*}{ Hanede kronik hastalık durumu } & Var & 68 & 25.09 \\
\hline & Yok & 203 & 74.91 \\
\hline
\end{tabular}

Kafkas Üniversitesi öğrencileri arasında yapılan çalışmada \%67'sinin hiç süt tüketmediği ortaya çıkmıştır. Araştırma sonucuna göre öğrencilerin \%33'nün her gün süt içtiği belirlenmiştir (Şimşek ve ark., 2005). Yine üniversite öğrencileri üzerine yapılan bir çalışmada, öğrencilerin $\% 71.33$ 'ü düzenli olarak süt tüketmediklerini, \%28.67'si ise düzenli olarak süt tükettiklerini belirtmişlerdir (Uzunöz ve Gülşen, 2007).

Süt ürünlerinin tüketim özelliklerine ait bilgiler Tablo 3' de verilmiştir. Ankete katılan hane halkı üyeleri, fermente süt ürünleri içinde günlük en çok peynir (\%50.55) ve pastörize yoğurt (\%21.77) tüketirken, gün aşırı olarak en çok süzme yoğurdu (\%40.96), daha sonra sırasıyla pastörize yoğurt (\%35.42) ve peynir (\%28.41) tercih ettiklerini belirtmişlerdir. Yapılan hesaplamalara göre kişi başına yıllık yoğurt tüketimi $32.84 \mathrm{~kg}$, kişi başına yıllık peynir tüketimi ise $18.48 \mathrm{~kg}$ olarak saptanmıştır. Diğer süt ürünleri günlük tüketimin önemli bir kısmını lor (\%9.96) ve kremalı pasta-tatlılar (\%8.12) oluşturmaktadır. Gün aşırı tüketim durumunda kremalı pasta-tatlılar (\%16.97) ile dondurma (\%14.76) ilk sıraları almıştır. Kremalı pasta ve tatılırın tüketim sıklı̆ıının gün aşırı ve diğer zamanlarda sırasıyla; \%16.97 ile \%23.62 oranlarında olduğu görülmektedir. Diğer süt ürünleri içinde en düşük tüketim oranını \%5.54 ile günlük dondurma oluşturmaktadır. Uzunöz ve Gülşen (2007) üniversite öğrencilerinin \%69'unun taze peynir ve \%31'inin ise olgunlaşmış peyniri tercih ettiklerini saptamıştır. 
Tablo 2. Hane halklarının süt tüketim özellikleri

Table 2. Milk consumption characteristics of households

\begin{tabular}{|c|c|c|c|c|c|c|c|}
\hline \multicolumn{2}{|c|}{ Süt tüketim özellikleri } & \multirow{2}{*}{$\begin{array}{c}\text { Sayı } \\
68\end{array}$} & \multirow{2}{*}{$\begin{array}{c}\% \\
25.09\end{array}$} & \multicolumn{2}{|c|}{ Süt tüketim özellikleri } & \multirow{2}{*}{$\begin{array}{l}\text { Sayı } \\
122\end{array}$} & \multirow{2}{*}{$\begin{array}{c}\% \\
48.22\end{array}$} \\
\hline \multirow{6}{*}{$\begin{array}{l}\text { Süt tüketim } \\
\text { sıklı̆̆ı }\end{array}$} & Her gün & & & \multirow{6}{*}{$\begin{array}{l}\text { Süt tüketme } \\
\text { nedeni }\end{array}$} & Besleyici olması & & \\
\hline & Haftada birkaç & 110 & 40.59 & & Alışkanlık & 37 & 14.62 \\
\hline & gün & 41 & 15.13 & & Sağlık (ilaç) nedeniyle & 21 & 8.30 \\
\hline & Ayda birkaç gün & 34 & 12.55 & & Lezzetli bulmam & 51 & 20.16 \\
\hline & Çok Nadir & 18 & 6.64 & & Büyüklerin zorlaması & 13 & 5.14 \\
\hline & Hiç & & & & Diğer & 9 & 3.56 \\
\hline \multirow{5}{*}{$\begin{array}{l}\text { Süt tüketim } \\
\text { miktarı (lt) }\end{array}$} & Aylık hane başına & 10.45 & - & \multirow{5}{*}{$\begin{array}{l}\text { Sütün yağlı } \\
\text { olup } \\
\text { olmamasına } \\
\text { göre tüketim } \\
\text { tercihi }\end{array}$} & Tam yağlı & 112 & 44.27 \\
\hline & Yıllık kişi başına & 37.43 & - & & Yarım yağlı & 98 & 38.74 \\
\hline & & & & & Yağsı & 12 & 4.74 \\
\hline & & & & & Fark etmez & 27 & 10.67 \\
\hline & & & & & Diğer & 4 & 1.58 \\
\hline \multirow{5}{*}{$\begin{array}{l}\text { Süt tüketimini } \\
\text { sevme durumu }\end{array}$} & Çok severim & 78 & 28.78 & \multirow{5}{*}{$\begin{array}{l}\text { Açık-kapalı } \\
\text { olarak süt } \\
\text { tüketim } \\
\text { durumu }\end{array}$} & & & \\
\hline & Severim & 128 & 47.23 & & Açık süt/sokak sütü & 41 & 16.21 \\
\hline & Az severim & 47 & 17.34 & & Pastörize/sterilize & 158 & 62.45 \\
\hline & Sevmem & 12 & 4.43 & & Fark etmez & 48 & 18.97 \\
\hline & Kesinlikle içmem & 6 & 2.22 & & Diğer & 6 & 2.37 \\
\hline \multirow{5}{*}{$\begin{array}{l}\text { Süt içme } \\
\text { alışkanlığı (yıl) }\end{array}$} & $0-1$ & 27 & 9.96 & \multirow{5}{*}{$\begin{array}{l}\text { Sütün } \\
\text { tüketilme } \\
\text { sicaklığ1 }\end{array}$} & Sicak & 64 & 25.30 \\
\hline & $2-3$ & 25 & 9.22 & & Soğuk & 83 & 32.81 \\
\hline & $4-6$ & 19 & 7.01 & & Illk & 85 & 33.60 \\
\hline & $7-9$ & 16 & 5.91 & & Fark etmez & 18 & 7.11 \\
\hline & 10 ve üstü & 184 & 67.90 & & Diğer & 3 & 1.18 \\
\hline \multirow{9}{*}{$\begin{array}{l}\text { Gün içinde süt } \\
\text { tüketim zamanı }\end{array}$} & & & & \multirow{9}{*}{$\begin{array}{l}\text { Süt tüketme } \\
\text { tercihi }\end{array}$} & Sade & 81 & 32.02 \\
\hline & & & & & Kakaolu & 56 & 22.14 \\
\hline & Sabah & 110 & 43.48 & & Şekerli & 22 & 8.70 \\
\hline & $\ddot{O} \breve{g} l e$ & 43 & 16.99 & & Meyveli & 14 & 5.53 \\
\hline & Akşam & 98 & 38.74 & & Şekersiz & 12 & 4.74 \\
\hline & Diğer & 2 & 0.79 & & Kahveli & 33 & 13.04 \\
\hline & & & & & Tatlılar içinde & 17 & 6.72 \\
\hline & & & & & Fark etmez & 14 & 5.53 \\
\hline & & & & & Diğer & 4 & 1.58 \\
\hline \multirow{7}{*}{$\begin{array}{l}\text { Süt tüketmeme } \\
\text { nedeni }\end{array}$} & Kokusu & 4 & 22.22 & \multirow{7}{*}{$\begin{array}{l}\text { Tüketilen süt } \\
\text { türü }\end{array}$} & & & \\
\hline & Tadı & 5 & 27.77 & & İnek & 220 & 81.18 \\
\hline & Alerjik rahatsızlık & 6 & 33.33 & & Keçi & 2 & 0.74 \\
\hline & Bulantı-kusma- & 1 & 5.56 & & Koyun & 5 & 1.85 \\
\hline & ishal & 1 & 5.56 & & Fark etmez & 25 & 9.22 \\
\hline & Sütle ilgili kötü anı & 1 & 5.56 & & Diğer & 1 & 0.37 \\
\hline & Diğger & & & & Hiçbiri & 18 & 6.64 \\
\hline
\end{tabular}

Araştırmada aylık süt ve süt ürünleri harcamasının gıda harcamaları içindeki oranının hanelerin \%59.41'inde \%20'nin altında olduğu saptanmıştır. Van ilinin merkezinde yapılan bir araştırmada hane halklarının aylık gelirlerinin \%8.63'ünü süt ve süt ürünleri harcamasına ayırdığı, ayrıca süt ve süt ürünleri harcamasının toplam gıda harcamaları içindeki payının ise \%21.45 olduğu belirlenmiştir (Andiç ve ark. 2002). İstanbul'da yapılan bir araştırmada ise bu oranlar; \%4.19 ve \%18.60 olarak saptanmıştır (Karakaya ve Akbay, 2013). Süt ve süt ürünlerini satın alma özellikleri Tablo 4' de yer almaktadır. Hane hakları süt ve süt ürünlerini \%80.07 oranında marketlerden satın alırken, satın alma yerinde en düşük payı \%2.58 ile bakkallar oluşturmuştur. Marketleri \%6.28 ile hayvancılık işletmelerinden satın alma seçeneği izlemiştir. Satın alma sıklığı incelendiğinde, ilk iki sırayı sırasıyla; \%41.70 ile gün aşırı ve \%21.40 ile her gün seçeneği almıştır. Hane halkı üyeleri süt ve süt ürünlerinin fiyatını değerlendirdiğinde $\% 44.65$ 'i yüksek, \%26.20'si çok yüksek bulurken, \%8.12'si ise düşük bulduğunu ifade etmiştir. Sağlığa uygun ve kaliteli bir süt için ödenebilecek fiyat farkı sorulduğunda ise \%53.87'si 0.5-1 TL/lt arasında fiyat farkını kabul edebileceğini belirtmiştir. 
Tablo 3. Hane halklarının süt ürünleri tüketim özellikleri

Table 3. Milk products consumption characteristics of households

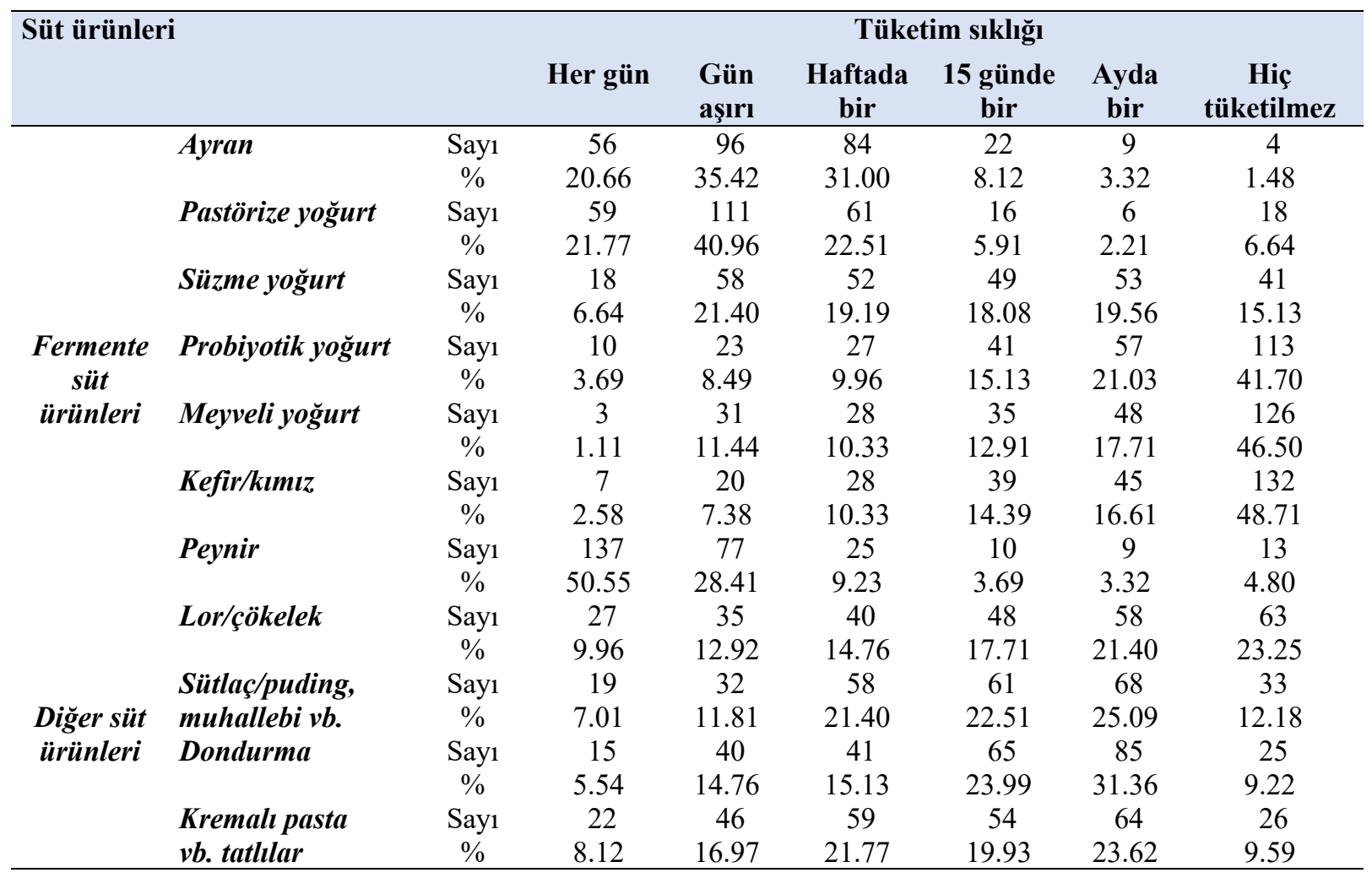

Tablo 4. Hane halklarının süt ve süt ürünleri satın alma özellikleri

Table 4. Milk and milk products purchasing characteristics of households

\begin{tabular}{|c|c|c|c|}
\hline \multicolumn{2}{|l|}{ Satın alma özellikleri } & \multirow{2}{*}{$\frac{\text { Sayı }}{217}$} & \multirow{2}{*}{$\begin{array}{c}\% \\
80.07\end{array}$} \\
\hline \multirow{5}{*}{$\begin{array}{l}\text { Süt ve süt ürünlerini } \\
\text { satın alma yeri }\end{array}$} & Market & & \\
\hline & Bakkal & 7 & 2.58 \\
\hline & Şarküteri & 8 & 2.95 \\
\hline & Sokak sütçüsü & 14 & 5.17 \\
\hline & Hayvancılık işletmesi & 17 & 6.28 \\
\hline \multirow{7}{*}{ Satın alma sıklığı } & Diğer & 8 & 2.95 \\
\hline & Her gün & 58 & 21.40 \\
\hline & Gün aşırı & 113 & 41.70 \\
\hline & Haftada bir & 54 & 19.93 \\
\hline & 15 günde bir & 34 & 12.54 \\
\hline & Ayda bir & 12 & 4.43 \\
\hline & Çok yüksek & 71 & 26.20 \\
\hline Süt ve süt ürünleri & Yüksek & 121 & 44.65 \\
\hline fiyatını & Uygun & 49 & 18.08 \\
\hline \multirow[t]{2}{*}{ değerlendirme } & Düşük & 22 & 8.12 \\
\hline & Çok Düşük & 8 & 2.95 \\
\hline Să̆liğa uygun ve & $0.50-1 \mathrm{TL} / \mathrm{lt}$ & 146 & 53.87 \\
\hline kaliteli bir süt için & $1-2 \mathrm{TL} / \mathrm{lt}$ & 52 & 19.19 \\
\hline ödenebilecek fiyat & $2-4 \mathrm{TL} / \mathrm{lt}$ & 39 & 14.39 \\
\hline farki & 4 TL/lt'den fazla & 34 & 12.55 \\
\hline
\end{tabular}

Ayar ve Nizamlığlu (2002) çalışmalarında katılımcıların süt ve ürünlerini alırken \%37'sinin kaliteye, \%26'sının tazeliğe, \%16'sının fiyatına ve \%12'sinin de markasına dikkat ettikleri yönündedir. Yılmaz ve Demirci (2001) ise üniversite öğrencilerinin \%2.5'inin markayı esas aldıklarını ve Şimşek ve ark. (2005) ise devamlı aynı markayı alırım diyenlerin \%46 ve marka değiştiririm diyenlerin ise \%54 olduğunu bildirilmişlerdir. 
Araştırmacıların sonuçlarının çalışmamız sonuçları ile benzer olduğunu söyleyebiliriz. Süt ve süt ürünleri tüketim miktarları diğer araştırma sonuçları ile karşılaştırıldığında, örneğin kişi başına yıllık süt tüketim miktarı; Çelik ve ark (2005) tarafından Şanlıurfa'da yapılan bir araştırmada 39.5 lt, Kahramanmaraş ilinde gerçekleştirilen bir araştırmada ise 37.57 lt (Akbay ve Tiryaki, 2007) olarak belirlenmiştir. Isparta'da yapılan bir araştırmada kişi başına yıllık 6.8 lt açık süt ve 24.47 lt ambalajlı süt tüketildiği (Demircan ve ark., 2011) belirlenmiştir. Erzincan ilinde yapılan bir araştırmada ise 59.52 lt olarak tespit edilmiştir (Erdal ve Tokgöz, 2011). Gözener ve Sayılı (2013) Tokat’ta yaptıkları bir araştırmada aylık kişi başı ambalajlı süt tüketim miktarını 3.65 lt, açık süt tüketim miktarını ise 5.76 lt olarak bildirmiştir. Karakaya ve Akbay (2014) tarafından İstanbul'da yapılan araştırma sonuçlarına göre, ailelerin \%26.5' 'inin açık süt, \%26.2'sinin pastörize süt ve \%87.7'sinin ise sterilize süt tükettiği tespit edilmiştir. $\mathrm{Bu}$ sonuçların bir kısmı bu araştırmanın sonuçlarıyla da uyumludur. Bu araştırmada süt tüketmeyenlerin oranı \%6.64 iken bu değer yukarıda adı geçen çalışmalarda farklılık gösterebilmekte ve \%18'lerin üzerine de çıkabilmektedir. Bunun nedeni, yaş, eğitim ve gelir düzeyi ile kronik hastalık ya da sağlık sorunları olabilmektedir (Karakaya ve Akbay, 2013).

Araştırmada, tüketicilerin süt ve süt ürünlerine yönelik ifadelere katılma düzeyine ait bulgular Tablo 5 'de verilmiştir. Süt ve süt ürünlerinin tadını beğeniyorum ifadesine verilen ortalama yanıt 4.24 ile en yüksek değerdir. Bunu sırasıyla; antibiyotik kalıntı madde düzeyi (3.38) ile üretim sırasındaki işlemlerdeki endişe (3.14) izlemektedir. En düşük değer, 2.27 ile süt ve süt ürünlerinin kolesterol içeriğine verilen yanıt olmuştur. Süt ve süt ürünlerine yönelik verilen yanttlarda tadın beğenilmesi diğer ifadelere göre oransal olarak daha yüksek değerler (Katılıyorum:\%35.42 ve Kesinlikle katıl1yorum: \%49.82 gibi) almıştır.

Tablo 5. Hane halka üyelerinin süt ve süt ürünlerine yönelik ifadelere katılma düzeyi

Table 5. Household members' participation level in statements related to milk and milk products

\begin{tabular}{|c|c|c|c|c|c|c|c|}
\hline \multirow[t]{2}{*}{ İfadeler } & & \multicolumn{5}{|c|}{ Katılma durumu * } & \multirow[t]{2}{*}{ Ortalama } \\
\hline & & 1 & 2 & 3 & 4 & 5 & \\
\hline Süt ve süt ürünlerinin tadını & Say1 & 8 & 14 & 18 & 96 & 135 & 4.24 \\
\hline beğeniyorum. & $\%$ & 2.95 & 5.17 & 6.64 & 35.42 & 49.82 & \\
\hline \multirow{2}{*}{$\begin{array}{l}\text { Süt ve süt ürünlerinin yağı beni } \\
\text { endişelendiriyor. }\end{array}$} & Sayı & 74 & 90 & 64 & 33 & 10 & 2.32 \\
\hline & $\%$ & 27.31 & 33.21 & 23.61 & 12.18 & 3.69 & \\
\hline \multirow{2}{*}{$\begin{array}{l}\text { Süt ve süt ürünlerinin şeker içeriği beni } \\
\text { endişelendiriyor. }\end{array}$} & Sayı & 80 & 88 & 47 & 40 & 16 & 2.35 \\
\hline & $\%$ & 29.52 & 32.47 & 17.34 & 14.76 & 5.91 & \\
\hline \multirow{2}{*}{$\begin{array}{l}\text { Süt ve süt ürünlerinin kolesterol içeriği beni } \\
\text { endişelendiriyor. }\end{array}$} & Sayı & 95 & 79 & 42 & 40 & 15 & 2.27 \\
\hline & $\%$ & 35.06 & 29.15 & 15.50 & 14.76 & 5.53 & \\
\hline \multirow{2}{*}{$\begin{array}{l}\text { Süt ve süt ürünleri üretimi sirasındaki işlemler } \\
\text { beni endişelendiriyor. }\end{array}$} & Sayı & 51 & 34 & 54 & 90 & 42 & 3.14 \\
\hline & $\%$ & 18.82 & 12.55 & 19.92 & 33.21 & 15.50 & \\
\hline \multirow{2}{*}{$\begin{array}{l}\text { Süt ve süt ürünlerindeki antibiyotik/kalıntı } \\
\text { madde düzeyi beni endişelendiriyor. }\end{array}$} & Sayı & 37 & 41 & 48 & 71 & 74 & 3.38 \\
\hline & $\%$ & 13.65 & 15.13 & 17.71 & 26.20 & 27.31 & \\
\hline
\end{tabular}

*1:Kesinlikle katılmıyorum, 2: Katılmıyorum, 3. Karasız, 4. Katılıyorum, 5. Kesinlikle katılıyorum

Araştırma sonuçlarına göre süt ürünleri tüketiminde sığır sütünün daha fazla bir pay aldığı belirlenmiştir. Ocak ve Önder (2014) yaptıkları araştırmada benzer olarak en fazla sığır türüne ait süt ürünlerinin tüketildiğini belirlemişlerdir. Bu şekildeki süt ve süt ürünlerinin hayvan türüne ait tüketim dağılımı TÜiK verileri ile de örtüşmektedir. Araştırmada hanelerde daha çok pastörize yoğurt tüketildiği saptanmıştır. Ayrıca eğitim durumu tüketilen peynir türü üzerinde etkili olabilmektedir. Örneğin koyun peynirinin gelir ve eğitim düzeyine bağlı olarak tüketim düzeyi de değişebilmektedir. Benzer durum keçi sütü ve ürünleri için de geçerlidir. Nitekim keçi sütü ve ürünleri tüketimi için bulunan sonuçlar Savran ve ark. (2011) ve Engindeniz ve ark. (2017)'nın bildirişlerinin 
altındadır. Bunun nedeninin, illerdeki hayvansal üretim tercihlerindeki farklılı̆ğn doğal bir sonucu olduğu düşünülmektedir. Yıllık ortalama yoğurt tüketimi; İstanbul'da $31.96 \mathrm{~kg}$ (Karakaya ve Akbay, 2013), Van'da ise $27.66 \mathrm{~kg}$ (Andiç ve ark., 2002) olarak saptanmıştır. Yıllık ortalama peynir tüketimi ise; İstanbul'da $14.65 \mathrm{~kg}$ (Karakaya ve Akbay, 2013), Van'da ise 17.63 kg (Andiç ve ark., 2002) olarak belirlenmiş̧ir.

Araştırma sonuçlarına göre hane halkı üyeleri süt ve süt ürünlerini daha çok marketten ve gün aşırı satın almaktadır. Günümüz tüketicilerinin gıda alışverişlerinde çoğunlukla marketleri kullandıkları görülmektedir (Öncül ve ark., 2019). Şanlıurfa'da yapılan araştırmada sütün satın alınmasında marketin tercih edilme oranının \%61.4 olduğu belirlenmiştir (Çelik ve ark., 2005). Ocak ve Önder (2014) tarafından Doğu Akdeniz'de yapılan bir araştırmada ise inek sütünün (\% 88.7) ve yoğurdunun (\% 90.8) çoğunlukla marketlerden satın alındığı saptanmıştır.

\section{Sonuç}

İzmir'in Bornova ilçesinin ekonomik yapısı, tarım ve hayvancılığa dayalı olmadığı için süt endüstrisinin geliştirilmesine yönelik çalışmaların yapılması ve teknolojik gelişmelerin yakından takip edilmesi bölge açısından önemli olacaktır. Bu yapılırken yerel yönetimlerce kayıt dışı olan sokak sütü satışının kontrol altına alınmasının sağlanması ve hijyenik koşullarda üretilmiş süt ve süt ürünlerinin arzını sağlayacak denetleme mekanizmasının kurulması gerekmektedir. Tüketicilerde açık sütün sağlıklı olduğuna ve ambalajlı sütlerde katkı maddesi olduğuna inanma gibi bazı doğru kabul ettikleri yanlış düşüncelerin değişmesi açısından, denetimler uzman kişilerce ve düzenli olarak yapılmalıdır. Hayvansal ürün talebini etkileyen faktörlerden biri de halk sağlığı riskleridir. $\mathrm{Bu}$ nedenle süt ve ürünlerinde de kalite standartları belirlenmeli, ürün kalitesi arttırılmalı ve gıda güvenilirliği sağlanmalıdır. Sonuç olarak; Türkiye'de bölgesel düzeyde beslenme alışkanlıkları ve tüketici tercihleri araştırmalarla saptanmalı, her bölgedeki tercihler dikkate alınarak ürün çeşitliliği ve farklı sunum şekilleri oluşturulmalıdır. Hayvansal protein tüketimini özendirmek, sağlıklı koşullarda üretilmiş sütü ve ürünlerinin tüketime sunulmasını sağlamak amacıyla toplumun bilgilendirilme ve bilinçlendirilmesine yönelik çalışmalar (afiş, broşür, belgesel ve spot filmler vb.) yapılmalıdır. Yapılacak çalışmalarda tüketicilerin kapalı süt ve ürünlerini tercih etmeleri konusu üzerinde önemle durulmalıdır. 


\section{Kaynakça}

Akbay, C., Tiryaki, G.Y. (2007). Tüketicilerin ambalajlı ve açık süt tüketim alışkanlıklarının karşılaştırmalı olarak incelenmesi: Kahramanmaraş örneği. KSÜ Fen ve Mühendislik Dergisi, 10(1):89-96.

Andiç S., Şahin, K., Koç, S. (2002). Van merkez 1lçe kentsel alanda süt tüketimi, Yüzüncü Yıl Üniv. Ziraat Fakültesi Tarım Bilimleri Dergisi, 12(2):33-38.

Arslan, Ö., Sevim, A., Güler, D., Saner, G. (2020). İzmir İlinde Tüketicilerin Çiğ Süt Satın Alma Kararlarını Etkileyen Faktörlerin Analizi. Atatürk Üniv. Ziraat Fakültesi Dergisi., 51 (3): 279-287.

Arslan, H, Engindeniz, S., Çınar, G. (2016). İzmir ili kentsel kesiminde odun dışı bitkisel orman ürünleri tüketiminin analizi üzerine bir araştırma, E.Ü. Ziraat Fakültesi Dergisi, 53(3):251-257.

Ayar, A, Nizamoğlu, M. (2002). Süt ve süt ürünlerinin tüketimi üzerine bazı sosyal faktörler ve tüketici özelliklerin etkisi. Gıda Yem Bil Teknol Derg, 1(1):25-31.

Bilgin, N. (1995). Sosyal Psikolojide Yöntem ve Pratik Çalışmalar, Sistem Yayıncılık, Ankara.

Black, R.E., Williams, S.M, Jones, I.E., Goulding, A. (2002). Children who avoid drinking cow milk have low dietary calcium intakes and poor bone health. American Journal of Clinical Nutrition. 76: 675-80.

Çebi, K., Özyürek, S., Türkyılmaz, D. (2018). Süt ve süt ürünleri tüketiminde tüketici tercihlerini etkileyen faktörler: Erzincan ili örneği. YYÜ Tarım Bilimleri Dergisi, 28(1):70-77.

Cevger, Y., Aral, Y., Demir, P., Sarı̈zkan, P. (2008). Ankara Üniversitesi Veteriner Fakültesi intern öğrencilerinde hayvansal ürünlerin tüketim durumu ve tüketici tercihleri. Ankara Üniversitesi Veteriner Fakültesi Dergisi, 55: 189-194.

Christopher, B.E., Nordin, N. (1997). Calcium and Osteoporosis. Nutrition, 13(7/8):664-686.

Çelik, Y., Karlı, B., Bilgiç, A., Çelik, Ş. (2005). Şanlıurfa ili kentsel alanda tüketicilerin süt tüketim düzeyleri ve süt tüketim alışkanlıkları, Tarım Ekonomi Dergisi 11(1):5-12.

Dal, N.E., Oral, M., Korkmaz, İ. (2018). Genç tüketicilerin içme sütü tüketim alışkanlıkları, The Journal of Academic Social Science Studies, 68:521-547.

Demir, G., Süer, O, Kaya, S. (2018). Investigation of milk and dairy products consumption of adolescents, Journal of Current Researches on Health Sector, 8(2): 37-48.

Demircan, V., Örmeci, MÇ, Kızılyar, G. (2011). Isparta ilinde ailelerin ambalajlı ve açık süt tüketim alışkanlıklarının karşılaştırmalı olarak incelenmesi. Süleyman Demirel Üniversitesi Ziraat Fakültesi Dergisi 6(2): 39-47.

Demirci, M, Kurultay, Ş., Öksüz, Ö. (1998). Tekirdağ ilinde içme sütü tüketim alışkanlıkları ve alışkanlıkları etkileyen faktörlerin belirlenmesi üzerine bir araştırma. İçme Sütü Sempozyumu Tebliğler Kitabı, Tekirdağ, s.140-157.

Engindeniz, S., Aktürk, D., Savran, A.F., Koşum, N., Taşkın, T., Kesenkaş, H., Gökmen, M., Uzmay, A., Çınar, G. (2017). İzmir, Çanakkale ve Balıkesir illerinde keçi sütü ve ürünleri tüketiminin analizi üzerine bir araştırma, E.Ü. Ziraat Fakültesi Dergisi, 54(4):385-395.

Erdal, G, Tokgöz, K. (2011). Tüketicilerin ambalajlı ve açık süt tüketim tercihlerini etkileyen faktörler: Erzincan ili örneği. KMÜ Sosyal ve Ekonomik Araştırmalar Dergisi. 13(20): 111-115.

Gözener, B., Sayılı, M. (2013). Tüketicilerin açık süt ve süt ürünleri tüketim tercihlerinin incelenmesi Tokat-Turhal ilçesi örneği. Sosyal Bilimler Araştırmaları Dergisi. 8(1):160-175.

Gündüz, O., Kılıç O, Emir M., Aydın, G. (2013). Süt ve süt ürünleri tüketiminde tüketici tercihlerini etkileyen faktörler. Samsun ili örneği, Gıda Teknolojileri Elektronik Dergisi, 8(1):36-43.

Hasipek S., Kaleli, N. (2002). Ankara Üniversitesi Ziraat Fakültesi’nin yurtta kalan kız ve erkek öğrencilerinin süt ve süt ürünleri tüketim sıklığı üzerine bir araştırma. Ankara Üniversitesi Ziraat Fakültesi Tarım Bilimleri Dergisi, 8(3): 204-207

Karagözlü, N., Karagözlü, C., Karaca, S., Eren S. (2005). Üniversite öğrencilerinde süt ve ürünleri tüketim alışkanlıkları ve beslenme bilinçleri üzerine bir araştırma. Celal Bayar Üniversitesi Fen Fakültesi Dergisi. 1(12):101-108.

Karakaya, E., Akbay, C. (2013). İstanbul ilinde tüketicilerin süt ve süt ürünleri tüketim alışkanlıkları, Uludağ Üniversitesi Ziraat Fakültesi Dergisi, 27(1):65-77.

Karakaya, E., Akbay, C. (2014). İstanbul ili kentsel alanda tüketicilerin açık ve paket süt tüketim alışkanlıkları. Tarım Ekonomisi Dergisi, 20(1):17-27.

Karakaya, E., Kızıloğlu, S. (2018). Bingöl ili kent merkezinde tüketicilerin süt ve süt ürünleri tüketim alışkanlıkları. KSÜ Tarım ve Doğa Dergisi, 21(Özel Sayı): 12-21.

Kayışçığlu, S., İçöz, A. (2012). Eğitim Düzeyinin Fast- Food Tüketim Alışkanlığına Etkisi. Tekirdağ Ziraat Fakültesi Dergisi 9(2): 16-19. 
MacDonald, L.E., Brett, J, Kelton, D, Majowicz, S.E., Snedeker, K., Sargeant, J.M. (2011). A systematic review and meta-analysis of the effects of pasteurization on milk vitamins, and evidence for raw milk consumption and other healthrelated outcomes. Journal of Food Protection, 74:1814-1832.

Malatacık, A.F. (2006). Elazığ ili merkez ilçede et, süt ve süt ürünleri tüketim yapısı. Yüksek Lisans Tezi. Yüzüncü Yıl Üniversitesi. Fen Bilimleri Enstitüsü Tarım Ekonomisi Anabilim Dalı, Van

Mazıcığlu, M.M., Öztürk, A. (2003). Üniversite 3 ve 4. sınıf öğrencilerinde beslenme alışkanlıkları ve bunları etkileyen faktörler, Erciyes Tıp Dergisi, 25(4):172-178.

Meneses, M, Pasqualino, J., Castells, F. (2012). Environmental assessment of the milk life cycle: the effect of packaging selection and the variability of milk production data. Journal of Environmental Management. 107:76-83.

Newbold, P. (1995). Statistics for Business and Economics. New Jersey: Prentice Hall.

Niyaz, Ö.C., İnan, İ.H. (2016). TR22 Güney Marmara Bölgesindeki tüketicilerin süt ve süt ürünleri tüketim düzeylerinin belirlenmesi, ÇOMÜ Ziraat Fakültesi Dergisi, 4 (2): 7-13.

Ocak, S., Önder, H. (2014). Süt ürünlerinde tüketici tercihini etkileyen faktörler ve gıda güvenliği bilinci, Hayvansal Üretim, 55(2):9-15

Onurlubaş, E., Çakırlar, H. (2016). Tüketicilerin süt ve süt ürünleri tüketimini etkileyen faktörlerin belirlenmesi üzerine bir araştırma. Çankırı Karatekin Üniversitesi Sosyal Bilimler Enstitüsü Dergisi, 7(1): 217-242.

Öncül, M., Sekman, Y., Kınıklı, F., Artukoğlu, M.M. (2019). Tüketicilerin gıda ürünleri satın alma tercihlerinin incelenmesi: İzmir ili örneği, Tarım Ekonomisi Dergisi, 25(2):207-217.

Örmeci, Kart ÇM., Demircan, V. (2014). Dünyada ve Türkiye’de Süt ve Süt Ürünleri Üretimi, Tüketimi ve Ticaretindeki Gelişmeler, Akademik Gida 12(1): 78-96.

Özbey, F. (2019). Üniversite Öğrencilerinin Süt ve Süt Ürünleri Tüketim Alışkanlıklarının Belirlenmesi. J Health Pro Res 2020; $2(1): 1-6$.

Özçıngırak, G., Engindeniz, S. (2019). İzmir'in kentsel kesiminde sera sebzeleri tüketiminin analizi, Tarım Ekonomisi Dergisi 25 (1):53-66.

Özel, G. (2008). Tüketicilerin süt tercihinde etkili olan faktörlerin incelenmesine yönelik bir araştırma. Süleyman Demirel Üniversitesi İktisadi ve İdari Bilimler Fakültesi Dergisi, 13(3): 227-240.

Özyürek, S., Yangılar, F., Çebi, K. (2019). Erzincan Üniversitesi Öğrencilerinin Süt ve Süt Ürünleri Tüketim Alışkanlıklarının İncelenmesi. Black Sea Journal of Agriculture 2(3): 119-125.

Para, G., Ülger, İ., Kaliber, M. (2018). Erciyes Üniversitesi Öğrencilerinin Süt Tüketim Alışkanlıklarının Belirlenmesi Üzerine Bir Araştırma. Iğdır Üniversitesi Fen Bilimleri Enstitüsü Dergisi, 8(1): 329-339.

Pereira A, Rey, P.V, Vence, X, Moreira, M.T, Gumersindo, Feijóo G. (2018). Fresh milk supply through vending machines: Consumption patterns and associated environmental impacts. Sustainable Production and Consumption, 15:119-130.

Savran, F., Aktük, D., Dellal, İ., Tatlıdil, F., Dellal, G., Pehlivan, E. (2011). Türkiye'de seçilmiş bazı illerde keçi sütü ve ürünleri tüketimine etkili faktörler, Kafkas Üniversitesi Veterinerlik Fakültesi Dergisi, 17(2):251-256.

Selçuk, Ş., Tarakçı, Z., Şahin, K., Coşkun, H. (2003). Yüzüncü Yıl Üniversitesi lisans öğrencilerinin süt ürünleri tüketim alışkanlıkları. Yüzüncü Yıl Üniversitesi Tarım Bilimleri Dergisi, 13(1): 23-31.

Şimşek, O, Çetin, C., Bilgin, B. (2005). İstanbul ilinde içme sütü tüketim alışkanlıkları ve bu alışkanlıkları etkileyen faktörlerin belirlenmesi üzerine bir araştırma. Tekirdağ Ziraat Fakültesi Dergisi 2(1): 23- 35.

Şeker, İ., Şeker P, Şahin, M., Özen VS, Akdeniz, A, Erkmen O, Kışlalığlu, İ, Sargın, G, Doğu GB. (2012). Elazığ İli Merkez İlçede tüketicilerin süt tüketim alışkanlıkları ve bu alışkanlıkları etkileyen faktörlerin belirlenmesi, F. Ü. Sağlık Bilimleri Veteriner Dergisi, 26 (3): 131-143

Terin, M. (2014). Dünya süt ve süt ürünleri üretim, tüketim, fiyat ve ticaretindeki gelişmeler. Iğdır Üniversitesi. Fen Bilimleri Enstitüsü Dergisi, 4(3): $53-63$.

Terin, M., Bilgiç, A., Güler, Oİ., Yavuz, F. (2015). Türkiye’de süt ürünleri tüketim harcamalarına etki eden faktörlerin analizi: çoklu heckman örneklem seçicilik sistem yaklaşımı. Tarım Bilimleri Dergisi, 21(4): 500-515.

TÜBER. (2015). Türkiye Beslenme Rehberi, Sağlık Bakanlığı Yayınları, Ankara

TÜIK, (2019). Adrese Dayalı Nüfus Kayıt Sistemi Sonuçları (2018). http://www.tuik.gov.tr/ , Erișim:17.12.2019

TBSA, (Türkiye Beslenme ve Sağlık Araştırması) (2010). Beslenme Durumu ve Alışkanlıklarının Değerlendirilmesi Sonuç Raporu. Sağlık Bakanlığı Sağlık Araştırmaları Genel Müdürlüğü, Hacettepe Üniversitesi Sağlık Bilimleri Fakültesi Beslenme ve Diyetetik Bölümü, Ankara Numune Eğitim ve Araştırma Hastanesi. Sağlık Bakanlığı Yayın No: 931, Ankara.

USK (Ulusal Süt Konseyi). (2019). Dünya ve Türkiye'de Süt Sektörü İstatistikleri. 2018 Süt raporu, https://ulusalsutkonseyi.org.tr/2018-sutraporu-2618, Erișim: 25.12.2019

Uzunöz, M., Gülşen, M. (2007). Üniversite öğrencilerinin süt ve süt ürünleri tüketim alışkanlıklarının belirlenmesi, Gıda Teknolojileri Elektronik Dergisi 2007;(3):15-21 
Ünal, R.N, Besler H.T. (2008). Beslenmede sütün önemi. Sağlık Bakanlığı Yayın No: 727, Ankara

Weetman, C. (2017). A Circular Economy Handbook for Business and Supply Chains: Repair, Remake, Redesign, Rethink. Kogan Page Limited, London

Yayar, R. (2012). Consumer characteristics influencing milk consumption preference. The Turkey case. Theoretical and Applied Economics, 7(7):25-42.

Yazıcı, ME. (2016). Kırşehir ilinde süt ve süt ürünleri tüketiminde tüketici algılarının belirlenmesi. Yüksek Lisans Tezi, Ahi Evran Üniversitesi Fen Bilimleri Enstitüsü. Zootekni Anabilim Dalı, Kırşehir.

Yılmaz, İ, Demirci, M. (2001). Üniversite öğrencilerinin beslenme alışkanlıkları. Dünya Gıda, 5: 83-86.

ZMO, (2019). Süt Raporu-2018. https://www.tmmob.org.tr/sites/default/files/zmo.pdf , Erişim: 25.12.2019. 